Musical Meaning 
This page intentionally left blank 


\section{Musical Meaning}

Toward a Critical History

LAWRENCE KRAMER

University of California Press

BERKELEY LOS ANGELES LONDON 
University of California Press

Berkeley and Los Angeles, California

University of California Press, Ltd.

London, England

(C) 2002 by the Regents of the University of California

Library of Congress Cataloging-in-Publication Data

Kramer, Lawrence, 1946-

Musical meaning : toward a critical history / Lawrence Kramer.

p. $\quad \mathrm{cm}$.

Includes bibliographical references (p. ) and index.

ISBN 0-520-22824-3 (cloth : alk. paper)

1. Music-Philosophy and aesthetics. 2. Music-History and criticism. 3. Subjectivity in music. 4. Music, Influence of.

I. Title.

ML3845 .K814 2002

781.1'7- dc21

2001027819

Manufactured in the United States of America
$\begin{array}{llllllllll}10 & 09 & 08 & 07 & 06 & 05 & 04 & 03 & 02 & 01\end{array}$
$\begin{array}{llllllllll}10 & 9 & 8 & 7 & 6 & 5 & 4 & 3 & 2 & 1\end{array}$

The paper used in this publication is both acid-free and totally chlorinefree (TCF). It meets the minimum requirements of ANsI/NISO Z39.481992 (R 1997) (Permanence of Paper). @) 